\title{
The Moderating Role of Ownership Concentration on the Relationship between Board Composition and Saudi Bank Performance
}

\author{
Omer Saeed HABTOOR ${ }^{1}$
}

Received: August 01, 2020 Revised: September 06, 2020 Accepted: September 10, 2020

\begin{abstract}
The main purpose of this study is to investigate the potential effect of ownership concentration on the relationship between board composition and bank performance. The study employs a sample of Saudi banks listed on Saudi stock exchange (TADAUWL) over the period from 2011 to 2018. To test the study hypotheses and control for endogeneity issues, the Ordinary Least Square (OLS) and the Two-Stage Least Squares (2SLS) techniques are used. The empirical results reveal a significant negative moderating effect of ownership concentration on the association between board composition and bank performance, which confirms the study argument and supports hypotheses. The results indicate that board composition in terms of independent board members, executive board members, and non-executive board members in banks with higher ownership concentration have a weaker positive influence on bank performance. For control variables, the results are almost consistent with theoretical perspectives and previous empirical evidence. The results of this study have important implications for regulatory authorities, companies, and market participants in Saudi Arabia and countries with high concentrated ownership to understand how ownership concentration could affect corporate governance and firm performance and to identify appropriate actions to protect board composition from the influence of ownership concentration.
\end{abstract}

Keywords: Ownership Concentration, Board Composition, Bank Performance, Moderating Role, Saudi Arabia

JEL Classification Code: G32, G34, L25, G21, O16

\section{Introduction}

The separation of ownership and control produces a potential conflict of interests between shareholders and managers who may act opportunistically to maximize their wealth at the expense of shareholders. Therefore, corporate governance has emerged as a need to curb the opportunistic behavior of executive management. The board of directors is considered the cornerstone of corporate governance, whose role is to monitor and direct management to act on behalf of

${ }^{1}$ First Author and Corresponding Author. [1] Assistant Professor, Department of Administrative Sciences, Community College, Northern Border University, Saudi Arabia [2] Department of Accounting, Faculty of Administrative Sciences, Aden University, Yemen [Postal Address: Community College Rafha, Al Qadisiyah Street, Rafha, 76321, Northern Borders Region, Saudi Arabia] Email: omer.habtoor@nbu.edu.sa ; omerhabtoor@hotmail.com

(c) Copyright: The Author(s)

This is an Open Access article distributed under the terms of the Creative Commons Attribution Non-Commercial License (https://creativecommons.org/licenses/by-nc/4.0/) which permits unrestricted non-commercial use, distribution, and reproduction in any medium, provided the original work is properly cited. shareholders (Fama \& Jensen, 1983; Healy \& Palepu, 2001; Jensen \& Meckling, 1976). Among board aspects, board composition is an indicator of board quality as independent, executive, and non-executive directors are the conspicuous features of the board that influence its effectiveness and, thus, firm performance (Chen \& Al-Najjar, 2012).

Despite the relatively extensive research on the direct relationship between board composition and firm performance, empirical evidence is mixed (Al Farooque et al., 2020; Amin \& Nor, 2019; Buallay et al., 2017; Combs et al., 2007; Ghabayen, 2012; Dang et al., 2020; Hamdan et al., 2019; Latif et al., 2020; Le et al., 2006; Villanueva-Villar et al., 2016), which draws attention to the need for further investigation on the reasons for the variety of findings. In response, a few studies explore in-depth the potential factors that may affect the direct relationships between board composition and firm performance. For example, Leung et al. (2014) examine whether family ownership in Hong Kong firms moderates the association between board and committee independence and firm performance. The results confirm the negative moderating role of family ownership on the board independence-firm performance relationship. 
Moreover, Uribe-Bohorquez et al. (2018) investigate the moderating role of institutional factors on the relationship between board independent and firm performance of an international sample of 2185 firms. The findings indicate that greater legal and judicial protection exerts a positive moderating impact on the association between board independence and firm performance.

The current study, therefore, aims to extend the literature on the potential factors affecting the association between board composition and firm performance by investigating whether ownership concentration moderates the relationship between board composition and Saudi bank performance. In addition to the potential direct relationship between ownership concentration and bank performance, this study assumes an indirect influence of ownership concentration on bank performance through moderating the association between board composition and bank performance in a country with high ownership concentration and interesting institutional setting, namely the Kingdom of Saudi Arabia.

The focus on the moderating role of ownership concentration on board composition-bank performance relationship in Saudi banking sectors is motivated by several reasons. First, this study is encouraged by the call of Almoneef and Samontaray (2019), Dalwai et al. (2015), and Leung et al. (2014) for further research on the relationship between corporate governance and performance, and potential factors, such as ownership concentration that could moderate this relationship in banking sector of Saudi Arabia and Gulf Cooperation Council (GCC) countries.

Second, corporate ownership is highly concentrated in Saudi Arabia with a unique structure, including several and different types of ownership with greater relative weights compared with their counterparts in Western countries (Habtoor et al., 2019a). Empirical evidence from Saudi Arabia largely reveal a negative impact of ownership concentration, represented by government (Al-janadi \& Rahman, 2015) and family ownership and institutional ownership (Habtoor et al., 2019a) on corporate disclosure. More specifically, Hamdan (2018) finds that firm performance is negatively affected by ownership concentration.

Third, in addition to their direct impact on firm performance, Saudi-controlling shareholders such as family and institutional owners have the ability to exert an indirect influence on firm performance through affecting corporate governance mechanisms, in general, and board composition, in specific, which in turn affect firm performance. It is argued that independent and non-executive directors may not be truly independent from management (Barako et al., 2006) due to the dominance of controlling shareholders on Saudi listed companies, and have a strong influence on board composition with a tendency to assign board members with less independence to better serve their interests ((SetiaAtmaja et al., 2009).
In sum, this study contributes to the literature as follows. First, this study offers an explanation for whey previous empirical evidence on the relationship between board composition and firm performance reveal equivocal results; ownership concentration moderates such relationship. Second, this study extends the growing corporate governance research on the potential factors affecting the direct association between corporate governance, in general, and board composition, in particular, and firm performance. Third, this study enriches the extant limited literature on the impact of board composition on firm performance and the interactions with ownership concentration. To the best of the author knowledge, this is the first study that investigates the moderating role of ownership concentration on the relationship between the three components of board composition (i.e., independent board members, executive board members, non-executive board members) and bank performance. Fourth, the results of the current study offer important practical implications for Saudi regulatory authorities, companies, and market practitioners. By confirming the negative role of ownership concentration on board composition and bank performance, Saudi Capital Market Authority (CMA) should make policies to protect corporate boards and their composition against the negative influence of concentrated ownership and controlling shareholders.

The rest of this study is organized as follows. Section 2 reviews the literature and discusses hypothesis development. Section 3 describes the research methodology. Section 4 reports empirical results and discussion. Section 5 concludes the study and highlights the limitations and future research.

\section{Literature Review and Hypothesis Development}

\subsection{Board Composition and Firm Performance}

Board composition is a keystone of board effectiveness and a determinant of firm performance. However, prior theoretical and empirical research on the relationship between board composition and firm performance reveal contradictory perspectives and equivocal results. For instance, resource dependency and legitimacy theories consider independent, non-executive, and outside directors, as a strategic resource to enhance firm performance through linking the company to external environment, securing critical resources, reducing environmental dependency, and aiding in establishing and supporting legitimacy (Daily \& Dalton, 1994). Moreover, agency theory suggests that independent and non-executive directors on the board would mitigate agency conflicts and control executive management opportunism as they are free from business relations with management, which could 
materially interfere with the exercise of their independent judgment and direct management towards better performance (Abraham \& Cox, 2007). On the other hand, agency theorists link executive board members with higher agency conflicts and lower firm performance due to their ability to act opportunistically to maximize their own benefits at the expense of the shareholders rights.

In contrast, stewardship and institutional theories have an opposite view that higher independent and non-executive members on the board, as outsiders, may lead to lower firm performance because they are unaware of the strengths and weaknesses of the firm, and unqualified to provide useful counsel and make efficient decisions, compared to insiders or executive members (Davis et al., 1997; Gaur et al., 2015). Alternatively, executive board members, as an essential part of team players, are not opportunities agents, but good stewards who act in the best interests of shareholders (Donaldson \& Davis, 1989).

Empirical evidence report mixed results. For example, Villanueva-Villar et al. (2016) find a positive association between independent board members and firm performance. Al Farooque et al. (2020) indicate that independent and outside directors on the board positively affect firm performance. While Latif et al. (2020) document a positive relationship between non-executive directors on the board and firm performance, Amin and Nor (2019) report a negative relationship between the two variables. Moreover, Akter et al. (2020), Combs et al. (2007), and Le et al. (2006) document an insignificant impact of independent and outside board members on firm performance. Furthermore, Majeed et al. (2020) find that board composition, as measured by the proportion of non-executive directors to total board members, is significantly and negatively associated with ROA, but insignificantly related to ROE for Pakistani banking sector. However, board composition in Chinese banking sector has an insignificant influence on both ROA and ROE. On the other hand, Abraham and Cox (2007) find that executive board members have a positive influence on corporate risk disclosure.

In Saudi context, Hamdan et al. (2019) find a positive impact of board independence on firm performance. However, Ghabayen (2012) reports a negative effect of board independence on firm performance. On the other hand, Buallay et al. (2017) find an insignificant impact of outside board members on firm performance.

\subsection{The Moderating Role of Ownership Concentration on the Relationship between Board Composition and Firm Performance}

Agency problems differ according to the volume of ownership and the type of firm owners. In the case of the dispersion of the company ownership, classic agency problems (type I) exist between shareholders (outsiders) and managers (insiders) due to the clear separation between ownership and management. In contrast, agency problems (type II) are common in firms with high concentrated ownership, which exist between the majority ownership (controlling shareholders) and minority ownership (noncontrolling shareholders) as a result of the unclear separation between the controlling shareholders and management.

Corporate ownership is highly concentrated in Saudi Arabia with a unique structure and different types of ownership (Habtoor et al., 2019a). Agency theory suggests that in a concentrated ownership environment, firms may face more complicated agency conflicts. Closely owned companies, especially by families, may face less agency conflicts between shareholders and managers. However, such firms are more likely to suffer from greater conflicts between the majority and minority shareholders, which encourage controlling shareholders to maximize their wealth at the expense of minority shareholders rights. Moreover, entrenchment theory links ownership concentration with lower performance. Higher levels of concentrated ownership could lead to entrenchment problem that creates incentives for controlling shareholders to expropriate wealth from other shareholders, which in turn negatively affect firm performance (Morck et al., 1988; Shleifer \& Vishny, 1997).

To do so, controlling shareholders can directly influence board decision-making, firm strategies and, thus, performance by imposing themselves in the top management team or as executive board members. In this regard, empirical evidence from Saudi Arabia largely confirms the direct negative impact of ownership concentration on firm performance (e.g., Buallay et al., 2017; Hamdan, 2018). Furthermore, controlling shareholders may exert an indirect influence on firm performance through affecting corporate governance mechanisms, in general, and board composition, in particular and, thus, controlling firm performance. Therefore, it is in the interests of such controlling shareholders to adopt weak forms of corporate governance systems to avoid strict monitoring by minority shareholders. The evidence indicates that boards of directors of Saudi firms are dominated by controlling shareholders who have a strong influence on board composition with a tendency to assign board members with less independence, such as their friends, relatives, or loyalists, to better serve their interests at the expense of the rights of minority shareholders. (Al Kahtani, 2013; Alamri, 2014; Albassam, 2014). Thus, it is rarely to find a clear separation of ownership and management or a real independence among board independent and non-executive members (Habtoor et al., 2019b).

While prior research focuses on the direct impact of board composition and ownership concentration on firm 
performance, no prior study empirically investigates whether the relationship between board composition and Saudi bank performance is affected by ownership concentration, which is the focus of this study. The Saudi Corporate Governance Regulations (SCGRs) categorize board members into three types, namely independent board members, executive board members, and non-executive board members. Based on the aforementioned theoretical and empirical research supplemented by the implications of Saudi context, the study hypotheses can be formulated as follows.

H1. Ownership concentration negatively moderates the relationship between independent board members and bank performance.

H2. Ownership concentration negatively moderates relationship between executive board members and bank performance.

H3. Ownership concentration negatively moderates the relationship between non-executive board members and bank performance.

\section{Research Methodology}

\subsection{Sample Selection and Data Collection}

To analyze the moderating role of ownership concentration on the association between board composition and bank performance, the sample consists of banks listed in the Saudi financial market (Tadawul) for the period from 2011 to 2018. Non-financial and other firms are dropped from the sample because they are less-regulated, and the applied accounting standards differ from those of banks. Out of the 96 bank-year observations, three observations are also excluded from the sample due to missing data for some independent and control variables. Data on variables is collected from the banks' annual reports downloaded from banks websites and Tadawul.

\subsection{Definition of Variables and Model Specification}

To test hypotheses, this study classifies variables included in the regression models into three categories, dependent variable, independent and moderator variables, and control variables, with full definitions as shown in Table 1.

First, the dependent variable is bank performance, which is measured in two different ways. Return on Assets (ROA) as accounting-based performance measure, and
Tobin's Q (Q) as a market-based performance measure (refer Table 1).

Second, to test the main hypotheses $(\mathrm{H} 1-\mathrm{H} 3)$ related to the moderating role of ownership concentration on the relationship between board composition and firm performance, the independent variables are board composition (i.e., independent board members, executive board members, non-executive board members), and the moderating variable is ownership concentration (i.e., the interaction between ownership concentration and independent board members, the interaction between ownership concentration and executive board members, the interaction between ownership concentration and nonexecutive board members) (refer Table 1).

Third, to control for potential omitted variable bias (Gujarati, 2003; Wooldridge, 2010) and to rule out alternative explanations for the mean results (Singh et al., 1986), the current study includes a number of control variables for board characteristics (board activity), ownership structure (government ownership), and firm-specific characteristics (bank size, bank profitability) (refer Table 1). There are extensive theoretical and empirical research that suggest a significant impact of these variables on firm performance (e.g., Ali et al., 2019; Altuwaijri \& Kalyanaraman, 2020; Bennouri et al., 2018; Hamdan, 2018; Harymawan et al., 2019; Latif et al., 2020; Nguyen \& Nguyen, 2020; Omer et al., 2020; Omer et al., 2020; Uribe-Bohorquez et al., 2018).

\subsection{Data Analysis}

Prior to analysis, the main assumptions of multivariate analysis, such as outliers, normality, linearity, multicollinearity, and heteroskedasticity are checked, and then corrected or controlled. The results of Shapiro-Wilk and Jarque-Bera tests for normality tests indicate that the data is not normally distributed. Therefore, the data is transformed into the normal scores using Van der Waerden approach, which transforms actual observations into their equivalent values on the normal distribution and mitigates the effect of outliers as well (Cooke, 1998). Normality is re-checked after data transformation, and the results of Shapiro-Wilk and Jarque-Bera tests are insignificant, which indicate that the data became normally distributed.

Linearity is checked using the scatter plots, which indicate no clear departure from linearity. Moreover, the Ramsey test is performed and the results indicate appropriate linear specification of the study regression models. Regarding multicollinearity, Pearson correlation matrix and variance inflation factor (VIF) tests indicate that multicollinearity is not a concern since the maximum values do not exceed the threshold value (0.80) of correlation and (10) of the VIF (Gujarati, 2003; Hair et al., 2010) as shown in Table 2. 
Table 1: Definition and measurement of variables

\begin{tabular}{|c|c|c|}
\hline Abbreviated Name & Full Name & Description / Measurement \\
\hline \multicolumn{3}{|c|}{ Dependent variable (firm performance) } \\
\hline ROA & Return on assets & Net income divided by book value of total assets \\
\hline Q & Tobin's Q & $\begin{array}{l}\text { Market value of total shares plus book value of debt } \\
\text { divided by book value of assets }\end{array}$ \\
\hline \multicolumn{3}{|c|}{ Independent variables (board composition) } \\
\hline B_Ind & independent board members & Percentage of independent members on the board \\
\hline B_Exe & executive board members & Percentage of executive members on the board \\
\hline B_NonExe & non-executive board members & Number of non-executive members on the board \\
\hline \multicolumn{3}{|c|}{ Moderator variable (ownership concentration) } \\
\hline Own_Con & Ownership concentration & $\begin{array}{l}\text { Percentage of bank shares held by large shareholders } \\
\text { who hold } 5 \% \text { and above of bank shares }\end{array}$ \\
\hline \multicolumn{3}{|c|}{ Control variables (firm, ownership, and board characteristics) } \\
\hline Bank_Size & Bank size & Total bank assets \\
\hline ROE & Profitability & Net income divided by book value of total equities \\
\hline Gov_Own & Government ownership & $\begin{array}{l}\text { The percentage of bank shares held by government } \\
\text { agencies }\end{array}$ \\
\hline B_Activity & board meeting frequency & Number of board meetings per year \\
\hline
\end{tabular}

Table 2: Pearson correlation matrix and VIF of variables

\begin{tabular}{|l|c|c|c|c|c|c|c|c|c|c|c|}
\hline Variables & VIF & $(\mathbf{1})$ & $\mathbf{( 2 )}$ & $\mathbf{( 3 )}$ & $\mathbf{( 4 )}$ & $\mathbf{( 5 )}$ & $\mathbf{( 6 )}$ & $\mathbf{( 7 )}$ & $\mathbf{( 8 )}$ & $\mathbf{( 9 )}$ & $\mathbf{( 1 0 )}$ \\
\hline (1) ROA & & 1.000 & & & & & & & & & \\
\hline (2) Q & & $0.555^{* *}$ & 1.000 & & & & & & & & \\
\hline (3) Bank_Size & 3.362 & $0.658^{* *}$ & 0.250 & 1.000 & & & & & & & \\
\hline (4) ROE & 1.813 & $0.790^{* *}$ & $0.602^{* *}$ & $0.458^{* *}$ & 1.000 & & & & & & \\
\hline (5) Gov_Own & 3.069 & $0.234^{*}$ & $-0.131^{*}$ & $0.631^{* *}$ & -0.038 & 1.000 & & & & & \\
\hline (6) B_Meet & 1.302 & 0.053 & 0.258 & $0.246^{*}$ & 0.028 & 0.124 & 1.000 & & & & \\
\hline (7) B_Ind & 1.317 & -0.038 & $-0.077^{*}$ & -0.152 & $-0.265^{*}$ & 0.090 & -0.126 & 1.000 & & & \\
\hline (8) B_Exe & 2.799 & -0.042 & -0.105 & -0.039 & -0.027 & 0.081 & $-0.318^{* *}$ & $-0.279^{* *}$ & 1.000 & & \\
\hline (9) B_NonExe & 3.184 & $0.309^{* *}$ & $0.335^{* *}$ & 0.181 & $0.294^{* *}$ & $-0.209^{*}$ & $0.297^{* *}$ & 0.040 & $-0.733^{* *}$ & 1.000 & \\
\hline (10) Own_Con & 1.245 & 0.130 & -0.060 & 0.190 & 0.178 & $0.287^{* *}$ & -0.065 & 0.018 & -0.085 & 0.131 & 1.000 \\
\hline
\end{tabular}

Note: ${ }^{*},{ }^{* *}$ significant at the 0.05 , and 0.01 levels (2-tailed) respectively.

Heteroskedasticity is also checked using Breusch-Pagan / Cook-Weisberg test, and the results are insignificant, which mean an absence of heteroskedasticity problem. Endogeneity is another concern in corporate governance and firm performance research (Giraldez-Puig \& Berenguer, 2018; Latif et al., 2020; Wintoki et al., 2012). The potential sources of endogeneity include omitted variable bias, unobservable heterogeneity, and simultaneity or reverse causation. Another source of endogeneity may arise when the current values of corporate governance variables are a function of past firm performance, which may seriously affect inferences (Wintoki et al., 2012). Prior empirical research suggests that corporate governance characteristics and firm performance are endogenous issues (Demsetz \& Lehn, 1985; Demsetz \& Villalonga, 2001; Valenti et al., 2011).

In dealing with endogeneity, Li (2016) investigates the prevailing econometric methods that deal with endogeneity issues, including GMM models, instrumental variables, fixed effects models, lagged dependent and independent 
variables, and control variables for dynamic models, and the empirical results indicate that any of these remedies can alleviate endogeneity bias to some degree. However, the combination of more than one method would be a viable remedy for endogeneity problems. Previous studies largely apply Instrumental Variable technique (IV) with lagged values to solve endogeneity bias (e.g., Chen \& Al-Najjar, 2012; Guest, 2008; Kao et al., 2019). Besides the using of OLS, the current study employs the Instrumental Variable technique (IV) using the 2SLS regression, with the first year lag for the dependent variable (ROA \& Q) and potential endogenous variables (board composition \& ownership concentration variables) as instruments (Al Farooque et al., 2019; Li, 2016).

To determine whether the models of this study have an endogeneity issue or not, the Durbin-Wu-Hausman test is performed to check for endogeneity. The DWH test rejects the null hypothesis of exogeneity for model 1 (ROA), indicating that board composition and ownership concentration variables are endogenously associated with ROA and, thus, the use of 2SLS with lagged values of dependent, independent, and moderator variables is an appropriate estimator for model 1 (ROA). Regarding the second model $(\mathrm{Q})$, the DWH test indicates on endogeneity problem as the test fails to reject the null hypothesis of exogeneity, which means that the OLS technique is more appropriate estimator for model $2(\mathrm{Q})$ than 2SLS.

To test the moderating effect in terms of the interaction between board composition and ownership concentration, this study employs Hierarchical regression analysis, and three regressions of analysis are performed for each model of bank performance (ROA \& Q). In the first regression, control variables are regressed against bank performance. In the second regression, the board composition and ownership concentration variables (independent and moderator variables) are included. In the third regression, the interactive terms of board composition and ownership concentration are added to test the moderating role of ownership concentration on the relationship between board composition and bank performance. Thus, the main models estimated are as follows:

Model 1 ROA $=\beta_{0}+\beta_{1}$ Bank_Size $+\beta_{2} \mathrm{ROE}+\beta_{3} \mathrm{Gov}$ Own $+\beta_{4} \mathrm{~B}$ - Activity $+\beta_{5} \mathrm{~B}$ Ind $+\beta_{6} \mathrm{~B} \_$Exe $+\beta_{7} \mathrm{~B}_{-}$ NonExe $+\beta_{8}$ Own_Con $+\beta_{9}$ Own_Con*B_Ind $+\beta_{10}$ Own Con*B_Exe $+\beta_{11}$ Own_Con*B_NonExe $+\varepsilon$

Model $2 \mathrm{Q}=\beta_{0}+\beta_{1}$ Bank_Size $+\beta_{2} \mathrm{ROE}+\beta_{3} \mathrm{Gov} \_$Own $+\beta_{4} \mathrm{~B} \_$Activity $+\beta_{5} \mathrm{~B} \_$Ind $+\beta_{6} \mathrm{~B} \_\mathrm{Exe}+\beta_{7} \mathrm{~B}$ NonExe + $\beta_{8}$ Own_Con $+\beta_{9}$ Own_Con*B_Ind $+\beta_{10}$ Own_Con*B

$\mathrm{Exe}+\beta_{11}$ Own_Con*B_NonExe $+\varepsilon$
Where, ROA is return on assets; Q is Tobin's q; Bank_Size is bank size; ROE is profitability; Gov_Own is government ownership; B_Activity is board meeting frequency; B_Ind is independent board members; $\mathrm{B}$ _Exe is executive board members; B_NonExe is non-executive board members; Own Con is ownership concentration; Own Con*B Ind is the interaction term between ownership concentration and independent board members; Own_Con*B_Exe is the interaction term between ownership concentration and executive board members; Own_Con*B_NonExe is the interaction term between ownership concentration and nonexecutive board members; $\varepsilon$ is error term.

\section{Empirical Results and Discussion}

\subsection{Descriptive Statistics}

Table 3 summarizes the descriptive statistics of variables included in the models of the study. The results reveal significant variations in the sample, which mitigate the possibility of sample selection bias. The variations among variables measures are almost consistent with prior evidence.

\subsection{Univariate Analysis}

The univariate analysis is reported in Table 2. The correlation matrix demonstrates the correlation among variables, which can be used as a mean to check for multicollinearity and to enhance the results of multivariate analysis (Field, 2013).

\subsection{Multivariate Analysis}

Table 4 reports the regression results of the impact of ownership concentration on the relationship between board composition and bank performance. Models 1 and 4 include only control variables. Across models, the results are not perfectly consistent with previous studies, however they provide evidence that performance is higher in bigger banks with higher profitability, higher government ownership, and active boards.

The inclusion of the main effects (board composition $\&$ ownership concentration variables) in models 2 and 5 of Table 4 increases the explanatory power of variance in bank performance $\left(\Delta \mathrm{R}^{2}=0.05^{* * *}, \Delta \mathrm{R}^{2}=0.06^{* * *}\right)$. The results reveal a significant positive association between board composition variables and bank performance, which is largely consistent with theoretical perspectives and empirical evidence (e.g., Al Farooque et al., 2019; Hamdan et al., 2019; Latif et al., 2020). On the other hand, ownership concentration has a negative impact on bank performance, which is in line with prior evidence ((e.g., Buallay et al., 2017; Hamdan, 2018). 
Table 3: Descriptive statistics of variables

\begin{tabular}{|l|c|c|c|c|c|c|c|}
\hline Variables & Obs & Mean & Std.Dev. & Min & Max & Skew. & Kurt. \\
\hline ROA & 93 & .019 & .005 & .008 & .033 & .417 & 3.661 \\
\hline Q & 93 & 1.067 & .072 & .949 & 1.323 & 1.252 & 4.781 \\
\hline Bank_Size & 93 & $1.62 e+08$ & $1.03 e+08$ & $2.77 e+07$ & $4.53 e+08$ & 1.093 & 3.935 \\
\hline ROE & 93 & .128 & .037 & .027 & .225 & .195 & 3.487 \\
\hline Gov_Own & 93 & .221 & .196 & 0 & .644 & .755 & 2.22 \\
\hline B_Activity & 93 & 5.527 & 1.665 & 3 & 10 & .79 & 2.566 \\
\hline B_Ind & 93 & .471 & .147 & .222 & 1 & 1.556 & 6.349 \\
\hline B_Exe & 93 & .067 & .058 & 0 & .2 & .066 & 2.023 \\
\hline B_NonExe & 93 & 9.118 & 1.062 & 7 & 11 & .53 & 2.256 \\
\hline Own_Con & 93 & .521 & .192 & .066 & .798 & -.632 & 2.414 \\
\hline
\end{tabular}

In models 3 and 6 of Table 4, the three interaction terms are added to test the study hypotheses predicting a weaker association between board composition and bank performance when ownership is highly concentrated. The addition of the interaction terms in models 3 and 6 explains more variance of bank performance $\left(\Delta R^{2}=0.05^{* * *}, \Delta R^{2}=\right.$ $\left.0.012^{* * *}\right)$. The results show a significant negative influence of the interaction term of Own_Con*B_Ind on both measures of bank performance (ROA \& Q), which indicates that the positive impact of independent board members on bank performance is weaker in banks with higher ownership concentration. This result strongly confirms the study argument and it clearly supports the first hypothesis. Regarding the second and third hypotheses, the results of models 3 and 6 in Table 4 reveal a significant negative impact of the interaction terms of Own_Con*B_Exe and Own_Con*B_NonExe on the market-based performance measure (Q). However, the impact of Own_Con*B_Exe and Own_Con*B_NonExe on the accounting-based performance measure (ROA) is insignificant. These results provide some support for hypothesis 2 and 3, and indicate that executive and non-executive board members in companies with higher concentration of ownership have a lower positive influence on bank performance.

\section{Conclusion, Limitation and Future Research}

The main objective of this study is to examine the moderating role of ownership concentration on the relationship between board composition in terms of independent, executive, and non-executive board members, and firm performance. The sample of this study consists of Saudi listed banks operating in the period from 2011 to 2018. To test the research hypotheses and to control for endogeneity, this study applies the OLS and 2SLS estimators. The empirical results confirm the theoretical perspectives and support the proposed negative moderating effect of ownership concentration on the board composition-bank performance relationship. The results indicate that the significant positive impact of independent, non-executive, and executive board members, on bank performance is weaker in banks with higher ownership concentration.

This study contributes to the literature in several ways. First, this study helps in explaining the potential factors / reasons behind the mixed results previously documented on the association between board composition and firm performance. The study argument and, thus, empirical evidence confirm that ownership concentration is among the potential drivers of the equivocal results on the direct relationship between board composition and bank performance. Therefore, this study extends the growing corporate governance research on potential factors affecting the direct association between corporate governance, in general, and board composition, in particular, and firm performance. Second, this study enriches the extant limited literature on the impact of board composition on firm performance and the interactions with ownership concentration. Fourth, the results of this study offer important practical implications for Saudi regulatory authorities, companies, and market practitioners. Saudi Capital Market Authority (CMA) should make policies to protect corporate boards and their composition against the negative influence of concentrated ownership and controlling shareholders. 
Table 4: Hierarchical regression results

\begin{tabular}{|c|c|c|c|c|c|c|}
\hline \multirow{3}{*}{ Variables } & \multicolumn{3}{|c|}{ OLS regression results } & \multicolumn{3}{|c|}{$2 S L S$ regression results } \\
\hline & Model 1 & Model 2 & Model 3 & Model 4 & Model 5 & Model 6 \\
\hline & $\mathbf{Q}$ & $\mathbf{Q}$ & $\mathbf{Q}$ & ROA & ROA & ROA \\
\hline \multicolumn{7}{|l|}{ Control variables } \\
\hline \multirow[t]{2}{*}{ Bank_Size } & 0.0146 & -0.0536 & -0.0446 & $0.321^{* * *}$ & $0.208^{* *}$ & $0.231^{* * *}$ \\
\hline & $(0.137)$ & $(0.145)$ & $(0.148)$ & $(0.0799)$ & $(0.0840)$ & $(0.0863)$ \\
\hline \multirow[t]{2}{*}{ ROE } & $0.662^{* * *}$ & $0.710^{* * *}$ & $0.678^{* * *}$ & $0.623^{* * *}$ & $0.689^{* * *}$ & $0.716^{* * *}$ \\
\hline & $(0.117)$ & $(0.119)$ & $(0.126)$ & $(0.0679)$ & $(0.0653)$ & $(0.0682)$ \\
\hline \multirow[t]{2}{*}{ Gov_Own } & -0.153 & -0.0481 & -0.147 & 0.0329 & $0.206^{* *}$ & $0.160^{*}$ \\
\hline & $(0.120)$ & $(0.139)$ & $(0.154)$ & $(0.0697)$ & $(0.0869)$ & $(0.0954)$ \\
\hline \multirow[t]{2}{*}{ B_Activity } & $0.267^{* * *}$ & $0.277^{* * *}$ & $0.270^{* * *}$ & -0.0528 & -0.0378 & -0.0668 \\
\hline & $(0.0861)$ & $(0.0921)$ & $(0.0944)$ & $(0.0501)$ & $(0.0548)$ & $(0.0578)$ \\
\hline \multicolumn{7}{|c|}{ Independent variables } \\
\hline \multirow[t]{2}{*}{ B_Ind } & & $0.178^{*}$ & 0.0695 & & $0.225^{\star * *}$ & $0.168^{*}$ \\
\hline & & $(0.0942)$ & $(0.0988)$ & & $(0.0803)$ & $(0.0908)$ \\
\hline \multirow[t]{2}{*}{ B_Exe } & & 0.252 & 0.127 & & $0.324^{* * *}$ & $0.228^{*}$ \\
\hline & & $(0.159)$ & $(0.173)$ & & $(0.108)$ & $(0.122)$ \\
\hline \multirow[t]{2}{*}{ B_NonExe } & & $0.258^{*}$ & 0.134 & & $0.397^{\star * *}$ & $0.354^{\star * *}$ \\
\hline & & $(0.152)$ & $(0.163)$ & & $(0.110)$ & $(0.115)$ \\
\hline \multicolumn{7}{|l|}{ Moderator variable } \\
\hline \multirow[t]{2}{*}{ Own_Con } & & $-0.142^{*}$ & $-0.166^{* *}$ & & $-0.138^{* * *}$ & $-0.158^{* * *}$ \\
\hline & & $(0.0839)$ & $(0.0830)$ & & $(0.0516)$ & $(0.0523)$ \\
\hline \multicolumn{7}{|l|}{ Interaction terms } \\
\hline \multirow[t]{2}{*}{ Own_Con*B_Ind } & & & $-0.330^{* *}$ & & & $-0.148^{*}$ \\
\hline & & & $(0.130)$ & & & $(0.0775)$ \\
\hline \multirow[t]{2}{*}{ Own_Con*B_Exe } & & & $-0.528^{*}$ & & & -0.235 \\
\hline & & & $(0.277)$ & & & $(0.159)$ \\
\hline \multirow[t]{2}{*}{$\begin{array}{l}\text { Own_Con*B_ } \\
\text { NonExe }\end{array}$} & & & $-0.365^{\star *}$ & & & -0.0572 \\
\hline & & & $(0.183)$ & & & $(0.102)$ \\
\hline \multirow[t]{2}{*}{ Constant } & $-0.152^{* *}$ & -0.121 & -0.118 & -0.0350 & 0.00882 & -0.0718 \\
\hline & $(0.0749)$ & $(0.0747)$ & $(0.0747)$ & $(0.0436)$ & $(0.0409)$ & $(0.0418)$ \\
\hline $\mathrm{N}$ & 93 & 93 & 93 & 93 & 91 & 91 \\
\hline F / Wald chi2 & $17.34^{* * *}$ & $10.13^{* * *}$ & $8.67^{* * *}$ & $263.9^{* * *}$ & $373.8^{* * *}$ & $406.5^{\star * *}$ \\
\hline $\mathrm{R} 2$ & 0.441 & 0.491 & 0.541 & 0.739 & 0.799 & 0.811 \\
\hline$\Delta R 2$ & & $0.05^{\star * *}$ & $0.05^{\star * \star}$ & & $0.06^{* * *}$ & $0.012^{* * *}$ \\
\hline
\end{tabular}

Note: ${ }^{*},{ }^{* *},{ }^{* * *}$ significant at the $0.10,0.05$, and 0.01 levels respectively. 
Although the results of this study are robust, they are subject to some limitations that evident in prior empirical studies. First, despite the inclusion of several control variables in regression models, the results may still subject to omitted variable bias. Second, the results of this study is robust for endogeneity, however, the performed remedies may not fully address different aspects of endogeneity, which could affect the results. Third, while this study offers empirical evidence on the moderating role of ownership concentration on board composition-bank performance relationship, further research may investigate different types of ownership and other potential factors that could moderate such relationship. Finally, a major limitation of this study is the relatively small sample size, which consists of 93 bankyear observations, and hence, future studies may expand the sample size by adding non-listed banks or using listed banks in GCC countries as they have similar ownership structure and institutional settings.

\section{References}

Abraham, S., \& Cox, P. (2007). Analysing the determinants of narrative risk information in UK FTSE 100 annual reports. British Accounting Review, 39(3), 227-248. https://doi. org/10.1016/j.bar.2007.06.002

Akter, S., Ali, H., Abedin, T., \& Hossain, B. (2020). Directors' remuneration and performance: evidence from the textile sector of Bangladesh. Journal of Asian Finance, Economics and Business, 7(6), 265-275. https://doi.org/10.13106/jafeb.2020. vol7.no6.265

Al Farooque, O. Al, Buachoom, W., \& Sun, L. (2020). Board, audit committee, ownership and financial performance -emerging trends from Thailand. Pacific Accounting Review, 32(1), 54-81.

Al Kahtani, F. S. (2013). Current practices of Saudi corporate governance: A case for reform. Doctorial dissertation, London, UK: Brunel University.

Alamri, M. A. (2014). Corporate governance and the board of directors in Saudi-listed companies. Doctorial dissertation, Dundee, UK: University of Dundee.

Albassam, W. M. (2014). Corporate governance, voluntary disclosure and financial performance: an empirical analysis of Saudi listed firms using a mixed-methods research design. Doctorial dissertation, Glasgow, UK: University of Glasgow.

Ali, S., Naseem, M. A., \& Ahmad, F. (2019). Moderating role of ownership in relationship between CSRD and firm performance. The Journal of Developing Areas, 53(3), 213-229.

Al-janadi, Y., \& Rahman, R. A. (2015). Does government ownership affect corporate governance and corporate disclosure ? Managerial Auditing Journal, 31(8), 871-890. https://doi. org/10.1108/MAJ-12-2015-1287

Almoneef, A., \& Samontaray, D. P. (2019). Corporate governance and firm performance in the Saudi banking industry. Banks and Bank Systems, 14(1), 147-158. https://doi.org/10.21511/ bbs.14(1).2019.13

Altuwaijri, B. M., \& Kalyanaraman, L. (2020). CEO educationperformance relationship: Evidence from Saudi Arabia. Journal of Asian Finance, Economics and Business, 7(8), 259-268. https://doi.org/10.13106/jafeb.2020.vol7.no8.259

Amin, S. I. M., \& Nor, S. M. (2019). Board diversity and firm performance in the construction, manufacturing, and trading/services industries. Asian Journal of Accounting and Governance, 12, 183-193.

Barako, D. G., Hancock, P., \& Izan, H. Y. (2006). Factors influencing voluntary corporate disclosure by Kenyan companies Dulacha. Journal Compilation, 14(2), 107-126.

Bennouri, M., Chtioui, T., Nagati, H., \& Nekhili, M. (2018). Female board directorship and firm performance: What really matters? Journal of Banking and Finance, 88, 267-291. https:// doi.org/10.1016/j.jbankfin.2017.12.010

Buallay, A., Hamdan, A., \& Zureigat, Q. (2017). Corporate governance and firm performance: evidence from Saudi Arabia. Australasian Accounting, Business and Finance Journal, 11(1), 78-99.

Chen, C. H., \& Al-Najjar, B. (2012). The determinants of board size and independence: Evidence from China. International Business Review, 21(5), 831-846. https://doi.org/10.1016/j. ibusrev.2011.09.008

Combs, J. G., Ketchen, D. J., Perryman, A. A., \& Donahue, M. S. (2007). The moderating effect of CEO power on the board composition-firm performance relationship. Journal of Management Studies, 44(8), 1299-1323. https://doi. org/10.1111/j.1467-6486.2007.00708.x

Cooke, T. E. (1998). Regression analysis in accounting disclosure studies. Accounting and Business Research, 28(3), 209-224.

Daily, C. M., \& Dalton, D. R. (1994). Corporate governance and the bankrupt firm: An empirical assessment. Strategic Management Journl, 15, 643-654.

Dalwai, T. A. R., Basiruddin, R., \& Rasid, S. Z. A. (2015). A critical review of relationship between corporate governance and firm performance: GCC banking sector perspective. Corporate Governance, 15(1), 18-30. https://doi.org/10.1108/CG-042013-0048

Dang, H. N., Pham, C. D., Nguyen, T. X., \& Nguyen, H. T. T. (2020). Effects of corporate governance and earning quality on listed Vietnamese firm value. Journal of Asian Finance, Economics and Business, 7(4), 71-80. https://doi.org/10.13106/ jafeb.2020.vol7.no4.71

Davis, J. H., Schoorman, F. D., \& Donaldson, L. (1997). Toward a stewardship theory of management. The Academy of Management Review, 22(1), 20-47. https://doi. org/10.2307/259223

Demsetz, H., \& Lehn, K. (1985). The structure of corporate ownership: Causes and consequences. Journal of Political Economy, 93(6), 1155-1177. 
Demsetz, h., \& Villalonga, B. (2001). ownership structure and corporate performance. Journal of Corporate Finance, 7 , 209-233.

Donaldson, L., \& Davis, J. H. (1989). CEO governance and shareholder returns: Agency theory or stewardship theory. Working paper presented at the Annual meeting of the Academy of Management, Washington, DC.

Fama, E. F., \& Jensen, M. C. (1983). Separation of ownership and control. The Journal of Law and Economics, 26(2), 301-325.

Field, A. (2013). Discovering Statistics: Using SPSS for Windows. London, UK: Sage Publications.

Gaur, S. S., Bathula, H., \& Singh, D. (2015), Ownership concentration, board characteristics and firm performance: a contingency framework. Management Decision, 53(5), 911931.

Ghabayen, M. A. (2012). Board characteristics and firm performance: Case of Saudi Arabia. International Journal of Accounting and Financial Reporting, 2(2), 168-200. https:// doi.org/10.5296/ijafr.v2i2.2145

Giraldez-Puig, P., \& Berenguer, E. (2018). Family female executives and firm financial performance. Sustainability, 10(11), 1-15. https://doi.org/10.3390/su10114163

Guest, P. M. (2008). The determinants of board size and composition: Evidence from the UK. Journal of Corporate Finance, 14(1), 51-72. https://doi.org/10.1016/j.jcorpfin.2008.01.002

Gujarati, D. N. (2003). Basic econometrics. New York, NY: McGraw-Hill.

Habtoor, O. S., Omer, W. K. H., \& Aljaaidi, K. S. (2019a). The impact of corporate ownership structure on corporate risk disclosure: Evidence from the Kingdom of Saudi Arabia. Business and Economic Horizons, 15(2), 325-356.

Habtoor, O. S., Omer, W. K. H., \& Aljaaidi, K. S. (2019b). The relationship between board committees and corporate risk disclosure in Saudi listed companies. International Journal of Advanced and Applied Sciences, 6(12), 41-57.

Hair, J. F., Black, W. C., Babin, B. J., \& Anderson, R. E. (2010). Multivariate data analysis (7th ed.). Upper Saddle River, NJ: Prentice Hall.

Hamdan, A. (2018). Board interlocking and firm performance: the role of foreign ownership in Saudi Arabia. International Journal of Managerial Finance, 14(3), 266-281. https://doi. org/10.1108/IJMF-09-2017-0192

Hamdan, A., Khamis, R., Anasweh, M., Al-hashimi, M., \& Razzaque, A. (2019). IT governance and firm performance: Empirical study from Saudi Arabia. SAGE Open, 9(2), 1-8. https://doi.org/10.1177/2158244019843721

Harymawan, I., Nasih, M., Ratri, M. C., \& Nowland, J. (2019). CEO busyness and firm performance: Evidence from Indonesia. Heliyon, 5(5), e01601. https://doi.org/10.1016/j.heliyon.2019. $\mathrm{e} 01601$

Healy, P. M., \& Palepu, K. G. (2001). Information asymmetry, corporate disclosure, and the capital markets: A review of the empirical disclosure literature. Journal of Accounting and Economics, 31(1-3), 405-440. https://doi.org/10.1016/S01654101(01)00018-0

Jensen, M. C., \& Meckling, W. H. (1976). Theory of the firm: Managerial behavior, agency costs and ownership structure. Journal of Financial Economics 3(4), 305-360.

Kao, M., Hodgkinson, L., \& Jaafar, A. (2019). Ownership structure, board of directors and firm performance: Evidence from Taiwan. Corporate Governance: The International Journal of Business in Society, 19(1), 189-216. https:/doi.org/10.1108/ CG-04-2018-0144

Latif, B., Voordeckers, W., Lambrechts, F., \& Hendriks, W. (2020). Multiple directorships in emerging countries: Fiduciary duties at stake? Business Ethics, 29(3), 629-645. https://doi. org/10.1111/beer.12275

Le, S. A., Walters, B., \& Kroll, M. (2006). The moderating effects of external monitors on the relationship between R\&D spending and firm performance. Journal of Business Research, 59(2), 278-287. https://doi.org/10.1016/j.jbusres.2005.04.003

Leung, S., Richardson, G., \& Jaggi, B. (2014). Corporate board and board committee independence, firm performance, and family ownership concentration: An analysis based on Hong Kong firm. Journal of Contemporary Accounting \& Economics, 10(1), 16-31. https://doi.org/10.1016/j.jcae.2013.11.002

Li, F. (2016). Endogeneity in CEO power: A survey and experiment. Investment Analysts Journal, 45(3), 149-162. https://doi.org/10 $.1080 / 10293523.2016 .1151985$

Majeed, M. K., Jun, J. C., Zia-ur-Rehman, M., Mohsin, M., \& Rafiq, M. Z. (2020). The board size and board composition impact on financial performance: An evidence from the Pakistani and Chinese's listed banking sector. Journal of Asian Finance, Economics and Business, 7(4), 81-95. https://doi.org/10.13106/ jafeb.2020.vol7.no4.81

Morck, R., Shleifer, A., \& Vishny, R. W. (1988). Management ownership and market valuation: An empirical analysis. Journal of Financial Economics, 20, 293-315.

Nguyen, T. N. L., \& Nguyen, V. C. (2020). The determinants of profitability in listed enterprises: a study from Vietnamese Stock Exchange. Journal of Asian Finance, Economics and Business, 7(1), 47-58. https://doi.org/10.13106/jafeb.2020. vol7.no1.47

Omer, W. K. H., Aljaaidi, K. S., \& Habtoor, O. S. (2020). The associations of corporate social responsibility and management characteristics with performance in Saudi Arabia. Polish Journal of Management Studies, 21(1), 251-264. https://doi. org/10.17512/pjms.2020.21.1.19

Omer, W. K. H., Aljaaidi, K. S., \& Habtoor, O. S. (2020). Board quality, audit quality and economic firm value: The case of manufactured Saudi's listed companies. Quality-Access to Success, 21(178). [In Press]

Setia-Atmaja, L. L.Y., Tanewski, G. A., \& Skully, M. T (2009). The role of dividends, debt and board structure in the governance of family controlled firms. Journal of Business Finance and 
Accounting, 36(7-8), 863-898. https://doi.org/10.1111/j.14685957.2009.02151.x

Shleifer, A., \& Vishny, R. W. (1997). A survey of corporate governance. The Journal of Finance, 52(2), 737-783.

Singh, J. V., House, R. J., \& Tucker, D. J. (1986). Organizational change and organizational mortality. Administrative Science Quarterly, 31, 587-611.

Uribe-Bohorquez, M., Martinez-Ferrero, J., \& Garcia-Sanchez, I. (2018). Board independence and firm performance: The moderating effect of institutional context. Journal of Business Research, 88, 28-43. https://doi.org/10.1016/j. jbusres.2018.03.005
Valenti, M., Luce, R., \& Mayfield, C. (2011). The effects of firm performance on corporate governance. Management Research Review, 34(3), 266-283.

Villanueva-Villar, M., Rivo-Lopez, E., \& Lago-Penas, S. (2016). On the relationship between corporate governance and value creation in an economic crisis: Empirical evidence for the Spanish case. BRQ Business Research Quarterly, 19(4), 233245. https://doi.org/10.1016/j.brq.2016.06.002

Wintoki, M. B., Linck, J. S., \& Netter, J. M. (2012). Endogeneity and the dynamics of internal corporate governance. Journal of Financial Economics, 105(3), 581-606. https://doi. org/10.1016/j.jfineco.2012.03.005

Wooldridge, J. M. (2010). Econometric analysis of cross section and panel data. Cambridge, MA: MIT Press. 